\title{
PEMBELAJARAN FISIKA DENGAN PENDEKATAN INKUIRI MELALUI METODE EKSPERIMEN DAN DEMONSTRASI DITINJAU DARI KREATIVITAS DAN MOTIVASI BERPRESTASI SISWA
}

\author{
Esthi Wulan Puspita ${ }^{1}$, Widha Sunarno ${ }^{2}$, Sarwanto $^{3}$ \\ ${ }^{1}$ Program Studi Magister Pendidikan Sains FKIP Universitas Sebelas Maret \\ Surakarta, 57126, Indonesia \\ nisae8705@gmail.com \\ ${ }^{2}$ Program Studi Magister Pendidikan Sains FKIP Universitas Sebelas Maret \\ Surakarta, 57126, Indonesia \\ widhasunarno@staff.uns.ac.id \\ ${ }^{3}$ Program Studi Magister Pendidikan Sains FKIP Universitas Sebelas Maret \\ Surakarta, 57126, Indonesia \\ sarwanto@staff.uns.ac.id
}

\begin{abstract}
Abstrak
Prestasi belajar siswa pada mata pelajaran fisika masih rendah, sehingga guru harus memperbaiki dan mengembangkan pembelajaran dengan cara menganalisis pengaruh metode pembelajaran terhadap hasil belajar siswa. Penelitian ini bertujuan untuk menganalisis pengaruh pembelajaran inkuiri dengan metode eksperimen dan demonstrasi, motivasi berprestasi, kreativitas siswa dan interaksinya terhadap prestasi belajar siswa pada materi listrik dinamis. Penelitian ini menggunakan penelitian eksperimen. Populasi penelitian adalah seluruh siswa kelas X di SMA Negeri 1 Gemolong, Sragen tahun pelajaran 2012/2013 sebanyak 2 kelas. Kelas eksperimen 1 dengan menggunakan metode eksperimen, dan kelas eksperimen 2 dengan menggunakan metode demonstrasi. Sampel penelitian diambil 2 kelas ditentukan dengan teknik purposive sampling. Teknik pengumpulan data menggunakan metode tes untuk mendapatkan data prestasi kognitif, sedangkan observasi untuk mendapatkan informasi nilai afektif dan psikomotor, menggunakan angket untuk nilai kreativitas dan motivasi berprestasi siswa. Data dianalisis dengan anava $2 \times 2 \times 2$. Hasil penelitian dapat disimpulkan bahwa: (1) ada perbedaan pengaruh pembelajaran fisika dengan pendekatan inkuiri menggunakan metode eksperimen dan demonstrasi terhadap nilai afektif dan tidak ada pengaruh pada prestasi kognitif dan nilai psikomotor; (2) tidak ada perbedaan pengaruh kreativitas siswa kategori tinggi dan rendah terhadap prestasi kognitif, afektif, dan psikomotor; (3) tidak ada perbedaan pengaruh motivasi berprestasi kategori tinggi dan rendah terhadap prestasi kognitif, nilai afektif, dan psikomotor; (4) ada interaksi metode eksperimen dan metode demontrasi dengan kreativitas kategori tinggi dan rendah terhadap nilai afektif, dan tidak ada pengaruh terhadap prestasi kognitif dan nilai psikomotor; (5) ada interaksi metode eksperimen dan metode demontrasi dengan motivasi berprestasi kategori tinggi dan rendah terhadap nilai afektif dan tidak ada interaksi pada prestasi kognitif dan nilai psikomotor; (6) tidak ada Interaksi antara krativitas siswa kategori tinggi dan rendah dengan motivasi belajar kategori tinggi dan rendah terhadap prestasi kognitif, nilai afektif, dan psikomotor; (7) tidak ada interaksi antara metode eksperimen dan metode demonstrasi dengan kreativitas kategori tinggi dan rendah dan dengan motivasi berprestasi kategori tinggi dan rendah terhadap prestasi kognitif, nilai afektif, dan psikomotor.
\end{abstract}

Kata Kunci: prestasi belajar; demonstrasi; eksperimen.

\section{Pendahuluan}

Kurikulum menjadi salah satu pedoman dalam pengembangan kreativitas peserta didik, mengingat peranannya dalam pembelajaran sangat penting untuk menghasilkan sumber daya manusia yang berkualitas. Dengan demikian sesuai dengan kurikulum KTSP dalam (Depdiknas,2007) pembelajaran fisika di SMA diharapkan dapat mempersiapkan peserta didik agar memiliki kemampuan: 
(1) membentuk sikap positif terhadap fisika dengan menyadari keteraturan dan keindahan alam serta mengagungkan kebesaran Tuhan Yang Maha Esa, (2) memupuk sikap ilmiah yaitu jujur, obyektif, terbuka, ulet, kritis dan dapat bekerjasama dengan orang lain, (3) mengembangkan pengalaman untuk dapat merumuskan masalah, mengajukan dan menguji hipotesis melalui percobaan, merancang dan merakit instrumen percobaan, mengumpulkan, mengolah, dan menafsirkan data, serta mengkomunikasikan hasil percobaan secara lisan dan tertulis, (4) mengembangkan kemampuan bernalar dalam berpikir analisis induktif dan deduktif dengan menggunakan konsep dan prinsip fisika untuk menjelaskan berbagai peristiwa alam dan menyelesaikan masalah baik secara kualitatif maupun kuantitatif, (5) menguasai konsep dan prinsip fisika serta mempunyai keterampilan mengembangkan pengetahuan, keterampilan dan sikap percaya diri sebagai bekal untuk melanjutkan pendidikan pada jenjang yang lebih tinggi serta mengembangkan ilmu pengetahuan dan teknologi, (6) menguasai konsep dasar fisika yang mendukung secara langsung pencapaian kompetensi program keahliannya, (7) menerapkan konsep dasar fisika untuk mendukung penerapan kompetensi program keahliannya dalam kehidupan sehari-hari, (8) menerapkan konsep dasar fisika untuk mengembangkan kemampuan program keahliannya pada tingkat yang lebih tinggi.

Berdasarkan hasil pengamatan dan wawancara terhadap Guru dan siswa di SMA Negeri 1 Gemolong diketahui bahwa prestasi belajar siswa pada mata pelajaran fisika masih rendah. Guru berusaha menjelaskan seluruh materi yang sejelasjelasnya dengan memberikan ceramah dengan harapan siswa mendapatkan materi sebanyakbanyaknya sehingga target kurikulum tercapai dengan kurang memperhatikan aspek proses, psikomotor dan efektif siswa.

Salah satu prinsip dalam proses pendidikan adalah siswa terlibat aktif dalam proses pembelajaran, dan untuk mewujudkan ini diperlukan motivasi dari siswa untuk mengikuti kegiatan pembelajaran yang sedang berlangsung. Pembelajaran fisika memerlukan suatu motivasi yang besar dari siswa untuk mampu berfikir secara abstrak dan memunculkan motivasi berprestasi. Motivasi berasal dari internal maupun dari eksternal. Guru berperan untuk memunculkan motivasi siswa dalam proses pembelajaran dengan menggunakan fasilitas pendidikan yang ada. Seorang remaja memiliki perkembangan kognitif tahap akhir, mereka mempunyai kemampuan mengkoordinasikan baik secara serentak maupun berurutan dua ragam kemampuan kognitif, yakni: 1) kapasitas menggunakan hipotesis; 2) kapasitas menggunakan prinsip prinsip abstrak. Syah (2010) mengungkapkan dengan kapasitas menggunakan hipotesis, seorang remaja akan mampu berfikir hipotesis, yaitu berfikir mengenai sesuatu khususnya dalam hal pemecahan masalah dalam menggunakan anggapan dasar yang relevan dengan lingkungan yang direspon.

Pemilihan metode belajar yang tepat akan berdampak positif bagi proses pembelajaran. Saat ini masih banyak pola pembelajaran yang diberikan secara konvensional sehingga cenderung prestasi belajar peserta didik masih sangat rendah, dan kurang aktif. Untuk mencapai tujuan pembelajaran fisika sebagaimana yang tercantum dalam kurikulum, tidak cukup hanya dengan mengunakan model pembelajarn konvensional atau tradisional, tetapi menggunakan model pembelajaran yang inovatif yang berdasarkan pada teori pembelajaran konstruktivisme.

Pembelajaran fisika memiliki peranan yang sangat penting bagi siswa, dalam pembelajaran ini siswa tidak hanya memperoleh konsep-konsep fisika tetapi juga menjadi sarana siswa untuk bisa memecahkan permasalahan yang terjadi dalam kehidupan sehari-hari. Sebagaimana yang tercantum dalam Kurikulum Tingkat Satuan Pendidikan (KTSP) terdapat 
beberapa tujuan untuk mata pelajaran Fisika dalam Permendiknas No. 24 Tahun 2006 Pembelajaran fisika dilaksanakan secara inkuiri ilmiah untuk menumbuhkan kemampuan berpikir, bekerja dan bersikap ilmiah serta berkomunikasi sebagai salah satu aspek penting kecakapan hidup. Fisika merupakan salah satu cabang IPA yang mendasari perkembangan teknologi maju dan konsep hidup harmonis dengan alam. Sebagai ilmu yang mempelajari fenomena alam, fisika juga memberikan pelajaran yang baik kepada manusia untuk hidup selaras berdasarkan hukum alam.

Pendekatan inkuiri merupakan model pembelajaran yang melatih siswa untuk belajar menemukan masalah, mengumpulkan, mengorganisasi, dan memecahkan masalah. Sagala (2010:197) mengungkapkan bahwa pendekatan inkuiri bertolak dari pandangan bahwa siswa sebagai subjek dan objek dalam belajar, mempunyai kemampuan dasar untuk berkembang secara optimal sesuai kemampuan yang dimiliki. Proses pembelajaran harus dipandang sebagai stimulus yang dapat menantang siswa untuk melakukan kegiatan belajar. Peran guru lebih banyak menerapkan sebagai pembimbing dan fasilitator belajar. Dengan demikian, siswa lebih banyak melakukan kegiatan sendiri atau dalam kelompok memecahkan permasalahan dengan bimbingan guru.

Metode eksperimen melibatkan siswa aktif dalam kegiatan pembelajaran. Roestiyah N.K (2001:79) mengungkapkan bahwa metode eksperimen diartikan sebagai cara penyajian bahan pelajaran siswa melakukan percobaan dengan mengalami untuk membuktikan sendiri sesuatu pertanyaan atau hipotesis yang dipelajari. Dalam proses belajar mengajar dengan metode eksperimen siswa diberi kesempatan untuk mengalami sendiri atau melakukan sendiri, mengikuti proses, mengamati suatu objek, menganalisis, membuktikan dan menarik kesimpulan sendiri tentang suatu objek. Berdasarkan beberapa pendapat diatas, dapat diambil suatu kesimpulan bahwa yang dimaksud dengan metode eksperimen atau percobaan adalah suatu tehnik mengajar yang menekankan pada keterlibatan siswa secara langsung untuk mengalami proses dan membuktikan sendiri hasil percobaan. Metode ini merupakan suatu metode mengajar yang termasuk paling sesuai untuk pelajaran fisika.

Pembelajaran menggunakan pendekatan inkuiri dengan metode eksperimen dan metode demonstrasi merupakan metode yang mengajak siswa untuk membuktikan konsep yang sedang dipelajari. Siswa melakukan pembuktian seperti para ilmuwan bekerja untuk membuktikan suatu konsep. Berbagai langkah-langkah harus dilakukan sesuai dengan petunjuk yang telah disediakan. Mereka mencatat hasil percobaan, menganalisa hingga menyimpulkan hasil percobaan. Tetapi selama ini memanfaatkan alat-alat praktikum masih kurang dalam pembelajaran karena keterbatasan alat dan waktu pembelajaran fisika.

Metode demonstrasi banyak digunakan dalam menyajikan pembelajaran IPA. Metode ini menghindarkan siswa dari kemampuan yang bersifat verbal, sebab siswa dihadapkan pada fakta yang nyata. Menurut Sagala (2010:210) metode demonstrasi merupakan salah satu metode yang paling sederhana dibandingkan dengan metode-metode mengajar lainnya, metode ini adalah petunjuk tentang proses terjadinya suatu peristiwa atau benda sampai pada penampilan tingkah laku yang dicontohkan agar dapat diketahui dan dipahami oleh peserta didik secara nyata atau tiruan. Sementara menurut Roestiyah N.K (2001:80) metode demonstrasi menunjukkan cara mengajar seorang instruktur/tim guru menunjukkan, memperlihatkan sesuatu proses sehingga seluruh siswa dapat melihat, mengamati, mendengar, mungkin meraba-raba dan merasakan proses yang dipertunjukkan guru".

Penelitian ini menggunakan pendekatan pembelajaran inkuiri. Mereka 
akan melakukan proses penyelidikan suatu masalah dengan bantuan bimbingan guru yang cukup besar. Akan tetapi keterlibatan siswa tetap dioptimalkan. Guru hanya membimbing agar siswa bekerja di dalam metode ilmiah yang sudah ada.

Salah satu materi fisika yang dipelajari di SMA adalah listrik dinamis. Berbagai fenomena lain di dalam kehidupan sehari-hari juga memerlukan konsep listrik dinamis di dalam penjelasannya. Setiap hari manusia membutuhkan listrik, sehingga akan timbul banyak pertanyaan dan pendapat tentang konsep listrik dinamis dan pemanfaatannya.

Melalui

konstruktivisme dengan pendekatan pembelajaran inkuiri dengan metode eksperimen dan metode demonstrasi keterlibatan siswa dapat dioptimalkan. Siswa mempelajari konsep listrik dinamis melalui kegiatan yang terstruktur. Mereka melakukan proses penyelidikan dan pembuktian sendiri. Akhirnya mereka diharapkan memahami konsep listik dinamis yang sebenarnya. Siswa akan mendapatkan kepuasan dari hasil yang mereka peroleh, karena mampu menjawab berbagai fenomena prinsip kerja beberapa alat teknologi. Selanjutnya siswa akan selalu berusaha untuk bertanya tentang fenomena listrik dinamis lainnya di dalam kehidupan sehari-hari, lalu mencari jawabannya secara ilmiah.

Kreativitas penuh membutuhkan suatu keseimbangan antara kemampuan analisis, kritis dan praktis. Barron dalam Asrori (2008:61) mengatakan bahwa kreativitas merupakan kemampuan untuk menciptakan sesuatu yang baru. Sesuatu yang baru disini bukan berarti harus sama sekali baru tetapi dapat juga sebagai kombinasi dari unsur-unsur yang telah ada sebelumnya. Menurut Utami Munandar dalam Asrori (2008:62) mendefinisikan kreativitas merupakan kemampuan yang mencerminkan kelancaran, keluwesan, dan orisinalitas dalam berfikir serta kemampuan untuk mengelaborasi suatu gagasan. Lebih lanjut Utami Munandar menekankan bahwa kreativitas sebagai keseluruhan kepribadian merupakan hasil interaksi dengan lingkungan. Sedangkan Rogers mendifinisikan kreativitas sebagai proses munculnya ide-ide baru kedalam suatu tindakan

Siswa yang memiliki motivasi belajar tinggi dalam belajar memungkinkan akan memperoleh hasil belajar yang tinggi pula. Menurut Nashar (2004:11) mengatakan bahwa motivasi belajar yang dimiliki siswa dalam setiap kegiatan pembelajaran sangat berperan untuk meningkatkan prestasi siswa.

Motivasi dipandang sebagai dorongan mental yang menggerakkan dan mengarahkan prilaku manusia termasuk prilaku belajar. Menurut McClelland dan Atkinson dalam Soemanto (2003:354), motivasi yang paling penting adalah motivasi berprestasi, dimana seseorang cenderung berjuang untuk mencapai sukses atau memilih suatu kegiatan yang berorientasi untuk tujuan sukses atau gagal. Siswa yang memiliki motivasi untuk mencapai prestasi mengharapkan sukses, namun jika gagal, akan berusaha lebih keras sampai sukses. Sebaliknya, siswa yang tidak memiliki sukses dalam berprestasi akan cenderung kehilangan motivasi, dan akan mengalihkan minat siswa pada kegiatan-kegiatan. Jadi, dapat disimpulkan bahwa motivasi berprestasi adalah kondisi/keadaan/dorongan seseorang melakukan sesuatu untuk mencapai tujuan dalam mendapatkan pemahaman konsep yang bermakna dalam meraih kesuksesan.

Berdasarkan pengertian diatas, maka penelitian ini bertujuan untuk menganalisis pengaruh pendekatan pembelajaran inkuiri dengan metode eksperimen dan metode demonstrasi, kreativitas, motivasi berprestasi siswa dan interaksinya terhadap prestasi belajar siswa pada materi listrik dinamis.

\section{Metode Penelitian}

Populasi dalam penelitian ini adalah siswa kelas X (sepuluh) sebanyak 6 kelas 
pada semester I SMA N 1 Gemolong 2012/2013. Teknik pengambilan sample yang digunakan dalam penelitian ini adalah teknik purposive sampling, yaitu diambil dua kelas secara langsung tanpa acak. Desain penelitian menggunakan desain faktorial $2 \times 2 \times 2$.

Instrumen yang digunakan berupa instrumen pelaksanaan pembelajaran berupa silabus, RPP, LKS dan instrumen pengambilan data berupa tes, lembar observasi dan angket. Teknik tes untuk mengukur prestasi kognitif, dengan menggunakan tes pilihan ganda dengan satu jawaban benar. Teknik non-tes berupa lembar observasi. Lembar observasi digunakan untuk menilai psikomotorik dan afektif siswa pada saat percobaan sedangkan angket digunakan untuk mengambil data kreativitas siswa dan prestasi berprestasi siswa. Uji validitas instrumen dibagi menjadi dua, yaitu validitas validitas dan releabilitas serta menggunakan uji $\mathrm{T}$ dua ekor untuk mengetahui kedua kelas dalam keadaan awal yang sama yang dilakukan oleh ahli sebelum diujicobakan ke lapangan. Teknik analisis data menggunakan uji anava $2 \times 2 \times 2$ dengan program PASW dengan signifikansi sebesar 0,05 .

\section{Hasil Penelitian dan Pembahasan}

Tabel 1.1. Ringkasan Uji Kruskall-Wallis Prestasi Kognitif

\begin{tabular}{clcl}
\hline hipo & Sumber Variansi & $\begin{array}{c}p- \\
\text { value }\end{array}$ & $\begin{array}{l}\text { Keputu } \\
\text { san Uji }\end{array}$ \\
\hline 1 & Metode & 0,149 & $\begin{array}{l}\mathrm{H}_{01} \\
\text { diterima }\end{array}$ \\
\hline 2 & Kreativitas siswa & 0,128 & $\begin{array}{l}\mathrm{H}_{02} \\
\text { diterima }\end{array}$ \\
\hline 3 & $\begin{array}{l}\text { Motivasi berprestasi } \\
\text { siswa }\end{array}$ & 0,715 & $\begin{array}{l}\mathrm{H}_{03} \\
\text { diterima }\end{array}$ \\
\hline 4 & Metode*kreativitas & 0,141 & $\begin{array}{l}\mathrm{H}_{04} \\
\text { diterima }\end{array}$ \\
\hline 5 & $\begin{array}{l}\text { Metode*motivasi } \\
\text { berprestasi }\end{array}$ & 0,461 & $\begin{array}{l}\mathrm{H}_{05} \\
\text { diterima }\end{array}$ \\
\hline 6 & Kreativiatas*motivasi & 0,112 & $\begin{array}{l}\mathrm{H}_{06} \\
\text { diterima }\end{array}$ \\
\hline 7 & $\begin{array}{l}\text { Metode*kreativitas* } \\
\text { motivasi }\end{array}$ & 0,215 & $\begin{array}{l}\mathrm{H}_{07} \\
\text { diterima }\end{array}$ \\
\hline
\end{tabular}

Tabel 1.1 merupakan ringkasan hasil uji Kruskall-Wallis prestasi kognitif siswa. Ketentuan untuk menolak $\mathrm{H}_{0}$ dalam penelitian ini adalah jika $p$-value lebih kecil dibandingkan dengan nilai taraf signifikansi $(\alpha=0,05)$.

Tabel 1.2. Ringkasan Uji Kruskall-Wallis Prestasi Afektif

\begin{tabular}{clcl}
\hline hipo & Sumber Variansi & $\begin{array}{c}p- \\
\text { value }\end{array}$ & $\begin{array}{c}\text { Keputus } \\
\text { an Uji }\end{array}$ \\
\hline 1 & Metode & 0,005 & $\begin{array}{l}\mathrm{H}_{01} \\
\text { ditolak }\end{array}$ \\
\hline 2 & Kreativitas siswa & 0,422 & $\begin{array}{l}\mathrm{H}_{02} \\
\text { diterima }\end{array}$ \\
\hline 3 & $\begin{array}{l}\text { Motivasi berprestasi } \\
\text { siswa }\end{array}$ & 0,682 & $\begin{array}{l}\mathrm{H}_{03} \\
\text { diterima }\end{array}$ \\
\hline 4 & Metode*kreativitas & 0,010 & $\begin{array}{l}\mathrm{H}_{04} \\
\text { ditolak }\end{array}$ \\
\hline 5 & $\begin{array}{l}\text { Metode*motivasi } \\
\text { berprestasi }\end{array}$ & 0,039 & $\begin{array}{l}\mathrm{H}_{05} \\
\text { ditolak }\end{array}$ \\
\hline 6 & Kreativiatas*motivasi & 0,648 & $\begin{array}{l}\mathrm{H}_{06} \\
\text { diterima }\end{array}$ \\
\hline 7 & $\begin{array}{l}\text { Metode*kreativitas*mot } \\
\text { ivasi }\end{array}$ & 0,056 & $\begin{array}{l}\mathrm{H}_{07} \\
\text { diterima }\end{array}$ \\
\hline
\end{tabular}

Tabel 1.2 merupakan ringkasan hasil uji Kruskall-Wallis prestasi kognitif siswa. Ketentuan untuk menolak $\mathrm{H}_{0}$ dalam penelitian ini adalah jika $p$-value lebih kecil dibandingkan dengan nilai taraf signifikansi $(\alpha=0,05)$.

Tabel 1.3. Ringkasan Uji Kruskall-Wallis Nilai psikomotor

\begin{tabular}{clrl}
\hline Hipo & Sumber Variansi & $\begin{array}{c}p- \\
\text { value }\end{array}$ & $\begin{array}{l}\text { Keputu- } \\
\text { san Uji }\end{array}$ \\
\hline 1 & Metode & 0,951 & $\begin{array}{l}\mathrm{H}_{0 \mathrm{~A}} \\
\text { diterima }\end{array}$ \\
\hline 2 & Kreativitas siswa & 0,737 & $\begin{array}{l}\mathrm{H}_{0 \mathrm{~B}} \\
\text { diterima }\end{array}$ \\
\hline 3 & $\begin{array}{l}\text { Motivasi } \\
\text { berprestasi siswa }\end{array}$ & 0,441 & $\begin{array}{l}\mathrm{H}_{0 \mathrm{c}} \\
\text { diterima }\end{array}$ \\
\hline 4 & Metode*kreativitas & 0,908 & $\begin{array}{l}\mathrm{H}_{0 \mathrm{AB}} \\
\text { diterima }\end{array}$ \\
\hline 5 & $\begin{array}{l}\text { Metode*motivasi } \\
\text { berprestasi }\end{array}$ & 0,827 & $\begin{array}{l}\mathrm{H}_{0 \mathrm{AC}} \\
\text { diterima }\end{array}$ \\
\hline 6 & $\begin{array}{l}\text { Kreativiatas*motiva } \\
\text { si }\end{array}$ & 0,664 & $\begin{array}{l}\mathrm{H}_{\mathrm{OBC}} \\
\text { diterima }\end{array}$ \\
\hline 7 & $\begin{array}{l}\text { Metode*kreativitas } \\
\text { *motivasi }\end{array}$ & 0,949 & $\begin{array}{l}\mathrm{H}_{\mathrm{OABC}} \\
\text { diterima }\end{array}$ \\
\hline & & & \\
\hline
\end{tabular}

Tabel 1.3 merupakan ringkasan hasil uji Kruskall-Wallis prestasi kognitifsiswa. Ketentuan untuk menolak $\mathrm{H}_{0}$ dalam penelitian ini adalah jika $p$-value lebih kecil 
dibandingkan dengan nilai taraf signifikansi $(\alpha=0,05)$.

\section{Hipotesis pertama}

Hasil Penelitian berdasarkan analisis data, diperoleh tidak ada pengaruh pembelajaran Fisika dengan pendekatan inkuiri menggunakan metode eksperimen dan demonstrasi terhadap prestasi kognitif dan psikomotor terhadap siswa, dan ada pengarurh terhadap nilai afektif siswa. Menurut Roestiyah (2008) pendekatan inkuiri dalam pembelajaran dapat lebih membiasakan kepada anak untuk membuktikan sesuatu mengenai materi pelajaran. Membuktikan dengan melakukan penyelidikan sendiri oleh siswa dibimbing guru, penyelidikan dilakukan para siswa baik di lapangan maupun laboratorium. Sehingga dalam hal ini metode eksperimen dan demonstrasi sangat cocok digunakan dalam pendekatan inkuiri. Berdasarkan Sagala (2010) menyebutkan bahwa dengan inkuiri dapat mengembangkan cara berfikir ilmiah, menempatkan siswa lebih banyak belajar sendiri, mengembangkan kreativitas dalam memecahkan masalah. Jadi, dengan adanya inkuiri akan membantu siswa untuk aktif dalam setiap pembelajaran. Namun, untuk menumbuhkan kreativitas yang baik harus memiliki kerja sama yang bagus antar sesama anggota kelompok, memahami perannya dalam kelompok, menerima pandangan/pendapat teman kelompok. Dengan demikian, akan terjalin kerja tim yang bagus.

Hasil observasi hanya beberapa siswa saja yang dapat aktif, yaitu siswa yang dipandang pandai dalam satu kelompok tersebut, baik siswa yang menggunakan eksperimen atau demonstrasi sehingga dengan demikian kurang adanya kerja sama yang bagus antar masing-masing anggota kelompok.

\section{Hipotesis kedua}

Hasil Penelitian berdasarkan analisis

data, diperoleh tidak ada pengaruh pembelajaran fisika dengan inkuiri menggunakan metode eksperimen dan demonstrasi dengan kreativitas siswa kategori tinggi dan rendah terhadap prestasi belajar siswa, baik kognitif ataupun psikomotor. Menurut Gagne dalam Winkel (1996: 323) untuk menemukan kondisikondisi peserta didik yang belajar informasi verbal, peserta didik harus memiliki motivasi yang tinggi, mampu menggunakan bentuk organisasi yang baik sehingga dapat menguasai teknik-teknik yang sesuai, memiliki ketajaman berpikir dalam menemukan konsep-konsep, memiliki kemampuan untuk membahasakan makna yang ada di dalam konsep agar dapat disimpan dalam memori dalam bentuk yang bermakna. Menurut Oakill (2011: 83-106) menyebutkan bahwa kreativitas siswa yang terdiri dari bahasa/kata-kata dan rentang angka dipengaruhi oleh kemampuan membaca dan kemampuan memahami katakata.

Meninjau pernyataan tersebut, tidak adanya interaksi antara pembelajaran inkuiri dengan kreativitas siswa terhadap prestasi dikarenakan dalam penelitian di lapangan, belum menganalisis adanya ketajaman berfikir siswa dalam pembelajaran, belum memberikan latihanlatihan soal untuk pengukuran kreativitas siswa sehingga siswa masih cenderung bingung dalam menyelesaikan tes akhir, belum semua siswa memiliki kemampuan membahasakan konsep dan disimpan dalam memori panjang meskipun telah dibentuk kelompok diskusi.

Hasil interview dengan beberapa siswa, menjelaskan bahwa tes kreativitas siswa bagi mereka adalah tes yang sangat asing dan belum pernah melihat jenis tes seperti itu sebelumnya. Sehingga banyak siswa yang tidak mengetahui cara mengerjakan tes kreativitas siswa, ditambah dengan tidak adanya petunjuk yang jelas, membuat para siswa bingung dalam mengerjakan.

\section{Hipotesis ketiga \\ Hasil Penelitian berdasarkan analisis \\ data, diperoleh nilai signifikansi}


pembelajaran fisika dengan motivasi berprestasi siswa kategori tinggi dan rendah terhadap prestasi kognitif, afektif, dan psikomotor sebesar 0,$715 ; 0,682 ; 0,441$, sehingga dapat diketahui bahwa nilai signifikansi lebih besar dibandingkan dengan nilai taraf signifikansi yang telah ditetapkan $(\alpha=0,05)$. Dengan demikian, tidak mempunyai cukup bukti untuk menolak $\mathrm{H}_{02}$, artinya tidak ada pengaruh pembelajaran fisika dengan inkuiri menggunakan metode eksperimen dan demonstrasi dengan kreativitas siswa kategori tinggi dan rendah terhadap prestasi belajar siswa, baik kognitif, afektif ataupun psikomotor.

Siswa yang memiliki motivasi untuk mencapai prestasi mengharapkan sukses, namun jika gagal, akan berusaha lebih keras sampai sukses. Sebaliknya, siswa yang tidak memiliki sukses dalam berprestasi akan cenderung kehilangan motivasi. Menurut McClelland dan Atkinson dalam Soemanto (2003: 354) motivasi berprestasi adalah kecenderungan seseorang berjuang untuk mencapai sukses atau memilih suatu kegiatan yang berorientasi untuk tujuan sukses atau gagal.

Meninjau pernyataan tersebut, siswa yang memiliki motivasi beprestasi akan berusaha lebih keras sampai mendapatkan keberhasilan meskipun gagal berkali-kali. Berdasarkan hasil interview dengan beberapa siswa, menyebutkan bahwa bagi siswa yang menggunakan metode eksperimen/demonstrasi tidak membuat termotivasi, karena karakter siswa yang acuh dengan adanya perlakuan dari guru, tidak percaya diri dengan adanya siswa lain yang memiliki kemampuan lebih baik, serta malu bertanya dengan satu kelompok. Namun, ketika diberikan kesempatan untuk mengerjakan di depan, siswa memiliki antusias yang tinggi. Hal ini dikarenakan karakter siswa yang sebenarnya memiliki keaktifan yang baik dari dalam diri.

\section{Hipotesis Keempat}

Hasil Penelitian berdasarkan analisis data tidak ada interaksi antara pembelajaran
Fisika dengan pendekatan Inkuiri menggunakan metode eksperimen dan demonstrasi dengan kreativitas siswa siswa kategori tinggi dan rendah terhadap prestasi kognitif dan nilai psikomotor, namun ada interkasi terhadap nilai afektif siswa. Bahwa tidak ada pengaruh antara metode dengan kreativitas siswa terhadap prestasi siswa, sehingga memungkinkan adanya tidak ada interaksi antara metode dengan kreativitas siswa terhadap prestasi kognitif dan psikomotor. Namun, ada interaksi antara pembelajaran dengan kreativitas siswa terhadap nilai afektif. Hal ini dikarenakan siswa yang menggunakan eksperimen dengan kreativitas siswa kategori tinggi memiliki rata-rata 45,00 dimana nilainya lebih tinggi daripada siswa yang memiliki kreativitas siswa kategori rendah yang bernilai 33,44. Sedangkan siswa yang menggunakan demonstrasi dengan kreativitas siswa kategori tinggi memiliki rata-rata nilai 26,51 lebih rendah daripada siswa yang memiliki kreativitas siswa kategori tinggi yang bernilai 26,50.

Kreativitas dalam diri siswa harus memiliki ketajaman berpikir dalam menemukan konsep-konsep. Hal ini sesuai dengan pernyataan Sagala (2010) tentang manfaat inkuiri, yaitu mendorong untuk menemukan ketrampilan berfikir, fakta dan konsep. Meninjau dua pernyataan tersebut, dapat diketahui bahwa terdapat interaksi antara inkuiri dengan kreativitas siswa.

Analisis uji lanjut Anava menghasilkan interaksi antara pendekatan inkuiri melalui eksperimen dan demonstrasi dengan kreativitas memberikan pengaruh signifikan terhadap nilai afektif. Sehingga dapat disarankan bagi guru untuk menggunakan metode eksperimen dan demonstrasi untuk mengembangkan faktor internal siswa khususnya kreativitas siswa pada materi listrik dinamis.

\section{Hipotesis Kelima}

Hasil Penelitian berdasarkan analisis data ada interaksi antara pembelajaran Fisika dengan pendekatan Inkuiri 
menggunakan metode eksperimen dan demonstrasi dengan motivasi berprestasi siswa kategori tinggi dan rendah terhadap prestasi afektif, dan tidak ada interaksi pada ranah kognitif dan psikomotor siswa. Dalam hal ini terlihat bahwa ada pengaruh pembelajaran dengan motivasi berprestasi terhadap prestasi afektif, sehingga sangat memungkin adanya interkasi antara pembelajaran dengan motivasi berprestasi terhadap prestasi siswa. Tetapi tidak ada pengaruh pada ranah kognitif dan psikomotor.

Barlia dalam Mamlock dan Naaman (2011) menyatakan bahwa motiviasi adalah variabel yang penting dalam mendorong kinerja keterampilan serta membangun pemahaman konsep yang bermakna. Dimana manfaat dari kedua metode yaitu dapat memotivasi pembelajar dalam pembelajaran karena siswa melakukan proses dalam percobaan tidak hanya menerima ceramah. Sehingga terdapat interaksi antara metode dengan motivasi berprestasi siswa pada ranah afektif.

Berdasarkan analisis uji lanjut Anava menghasilkan bahwa interaksi metode eksperimen dan demonstrasi dengan motivasi berprestasi memiliki pengaruh yang signifikan. Sehingga dapat disarankan bagi guru untuk menggunakan metode eksperimen dan demonstrasi untuk mengembangkan faktor internal siswa khususnya motivasi berprestasi pada materi gerak getaran.

\section{Hipotesis Keenam}

Hasil Penelitian berdasarkan analisis data tidak ada interaksi antara kreativitas siswa dan motivasi berprestasi kategori tinggi dan rendah terhadap prestasi kognitif, afektif dan psikomotor. Munandar (2012: 71) menyebutkan ciri-ciri kepribadian kreatif yang diharapkan oleh bangsa Indonesia, yaitu: (1) mempunyai rasa ingin tahu; (2) mempunyai daya imajinasi; (3) tertantang oleh kemajemukan; (4) berani mengambil resiko. Namun, dari hasil interview sebagian siswa dalam pembelajaran memiliki rasa ingin tahu lemah. Hal ini terlihat bahwa siswa sangat tergantung dengan guru, selain itu siswa juga kurang berani mengambil resiko.

\section{Hipotesis Ketujuh}

Hasil Penelitian berdasarkan nalisis data tidak ada interaksi antara metode pembelajaran dengan kreativitas siswa dan motivasi berprestasi kategori tinggi dan rendah terhadap prestasi belajar, baik kognitif dan psikomotor. Menurut Gagne dalam Winkel (1996) menjelaskan bahwa siswa memiliki motivasi yang tinggi sehingga informasi yang didapatkan tidak hanya disimpan dalam memori jangka pendek, tetapi dalam memori jangka panjang sehingga akan mendapatkan pembelajaran yang bermakna. Namun, dari hasil interview, sebagian siswa dalam menyerap materi masih disimpan dalam memori jangka pendek yaitu berupa hafalan, sehingga ketika mengerjakan latihan soal dan ulangan harian, siswa masih banyak yang mengalami kesulitan dalam menyelesaikan soal yang diberikan. Munandar (2004: 71) menyebutkan ciri-ciri kepribadian kreatif yang diharapkan oleh bangsa Indonesia, yaitu: (1) mempunyai rasa ingin tahu; (2) mempunyai daya imajinasi; (3) tertantang oleh kemajemukan; (4) berani mengambil resiko. Sehingga hal ini sangat berpengaruh pada hasil yang diperoleh. Selain itu siswa juga kurang memiliki rasa ingin tahu yang lebih ini terlihat dari hasil interview dan angket yang telah disebar. Sehingga pernyataan diatas sangat berpengaruh terhadap hasil penelitian.

\section{Kesimpulan dan Rekomendasi}

Hasil Penelitian berdasarkan analisis data dan pembahasan, dapat menghasilkan kesimpulan sebagai berikut: (1) ada perbedaan pengaruh pembelajaran fisika dengan pendekatan inkuiri menggunakan metode eksperimen dan demonstrasi terhadap nilai afektif dan tidak ada pengaruh pada prestasi kognitif dan nilai psikomotor; (2) tidak ada perbedaan 
pengaruh kreativitas siswa kategori tinggi dan rendah terhadap prestasi kognitif, afektif dan psikomotor; (3) tidak ada perbedaan pengaruh motivasi berprestasi kategori tinggi dan rendah terhadap prestasi kognitif, nilai afektif dan psikomotor; (4) ada interaksi metode eksperimen dan metode demontrasi dengan kreativitas kategori tinggi dan rendah terhadap nilai afektif, dan tidak ada pengaruh terhadap prestasi kognitif dan nilai psikomotor; (5) ada interaksi metode eksperimen dan metode demontrasi dengan motivasi berprestasi kategori tinggi dan rendah terhadap nilai afektif dan tidak ada interaksi pada prestasi kognitif dan nilai psikomotor; (6) tidak ada Interaksi antara krativitas siswa kategori tinggi dan rendah dengan motivasi belajar kategori tinggi dan rendah terhadap prestasi kognitif, nilai afektif dan psikomotor; (7) tidak ada interaksi antara metode eksperimen dan metode demonstrasi dengan kreativitas kategori tinggi dan rendah dan dengan motivasi berprestasi kategori tinggi dan rendah terhadap prestasi kognitif, nilai afektif dan psikomotor

Guru dalam menyampaikan konsepkonsep fisika diperlukan metode pembelajaran yang mampu membuat siswa tertarik untuk mempelajari fisika, senang, dan mudah untuk menerima serta memahami materi. Sejalan dengan diberlakukannya kurikulum 2013 dalam Permendikbud Nomor 81 A sebaiknya guru sudah mulai menerapkan pendekatan saintifik (Scientific Aproach) dalam pembelajaran melalui lima langkah atau tahapan pembelajaran yaitu mengamati (observing), menanya (questioning), menalar (associating), mencoba (experimenting) dan membentuk jaringan (networking). Metode yang digunakan dapat berupa metode eksperimen maupun demonstrasi.

\section{Daftar Pustaka}

Asrori, Muhammad. (2008). Paikologi Pembelajaran. Bandung: Wacana Prima.

Budiyono. (2009). Statistika untuk Penelitian Edisi ke-2. Surakarta: UNS Press.

Depdiknas. (2007). Model Kurikulum Tingkat Satuan Pendidikan Untuk Sekolah Menengah Kejuruan. Jakarta: Direktorat Jenderal Pendidikan Dasar dan Menengah.

Oakhil J, Nicola Yuill dan Alan Garnham. (2011). The differential relations between verbal, numerical and spatial working memory abilities and children's reading comprehension. (4(1), 83-106).

Mamlok R dan Naaman. (2011). 'How Can Motivate High School Students to Study Science?'. Science Educational International. (22 (1): 5-17).

Munandar, Utami. (2012). Pengembangan KreativitasAnak Berbakat. Jakarta: PT.

Nashar. (2004). Peranan Motivasi dan Kemampuan Awal dalam Kegiatan Pembelajaran. Jakarta: Bina Aksara.

Roestiyah NK. (2001). Strategi Belajar Mengajar. Jakarta: Rineka Cipta.

Sagala, Syaiful. (2010). Konsep dan Makna Pembelajaran. Bandung: Alfabetha.

Soemanto, Wasty. (2003). Psikologi Pendidikan. Jakarta: Rineka Cipta.

Syah, Muhibbin. (2010). Psikologi Pendidikan. Bandung: Penerbit Pt. Remaja Rosdakarya

Winkel, W.S. (1996). Psikologi Pengajaran. Jakarta: Grasindo. 